\title{
Career Self-efficacy of the Black Engineer in the U.S. Government Workplace
}

\section{Mr. Scott Hofacker PE, US Army}

Dr. Hofacker is a recent graduate of The George Washington University's Graduate School of Education and Human Development. His research area is the career self-efficacy of racially underrepresented minorities in the engineering workplace. Dr. Hofacker is also the Concept Design and Assessment Focus Area Lead for the US Army's Aviation and Missile Research, Development and Engineering Center at Redstone Arsenal, Alabama. He is responsible for the strategic planning of science and technology efforts related to concepts and designs to support the next generation of future vertical lift aircraft. He has over 25 years of experience in science and technology, industrial and systems engineering and program management. He also holds a Bachelor of Industrial Engineering degree from Auburn University, a Master of Science in Engineering degree from the University of Alabama in Huntsville, and an MBA from Florida Institute of Technology. 


\title{
Career Self-efficacy of the Black Engineer in the U.S. Government Workplace
}

\begin{abstract}
This paper reports the results of a quantitative, nonexperimental, cross-sectional, one-time, webbased survey on the career self-efficacy ${ }^{1}$ of self-selected black engineers in the engineering workplace-a workplace that has been described as a "haven of whiteness and masculinity"3,p.14 and "pale” and "male»4,p.86. Engineering has been a key component of the U.S.'s global technological superiority. However, U.S. racial demographics are changing. The number of whites currently in the workforce and the number of whites entering the workforce will decrease over the next several decades. Given current college and university graduation rates by race, the number of underrepresented minority engineers is not on a path to maintain the engineering workforce. Science, technology, engineering, and mathematics (STEM) programs attempt to address this shortfall with much attention in primary and secondary schools, and in college.
\end{abstract}

Additionally, U.S. companies spend $\$ 8$ billion to $\$ 10$ billion annually on diversity programs to create opportunity and inclusion strategies for underrepresented minorities. Even with this focus on diversity, the underrepresented engineer enters an engineering workforce where career attainment is less likely than for the majority, thus creating a gap between attainment and opportunity. Career self-efficacy_a belief in one's ability to plan, implement, and execute the courses of action required to attain in one's career-may be one way to understand this gap between career attainment and career opportunity, as suggested by social cognitive career theory ${ }^{11}$. However, no data on the career self-efficacy of engineers in the workplace exists.

During this study, career self-efficacy of black engineers was measured using an adapted 25question Career Decision Self-efficacy Short Form² (CDSE-SF) instrument, assessing career self-efficacy subscales of self-appraisal, occupational information gathering, goal setting, planning, and problem solving. The results of a survey of 131 black engineers in a large government engineering organization indicate that the career self-efficacy of black engineers is high. While the CDSE-SF is highly respected and widely used, the recommendation is made to further develop and validate the career self-efficacy scale for the workplace. Additionally, outcome expectations of black engineers should also be explored to gather additional human resource data to provide a complete assessment of the social cognitive career theory model ${ }^{11}$.

\section{Introduction}

U.S. private and public organizations spend nearly $\$ 10$ billion annually on diversity programs and inclusion strategies ${ }^{5,6}$. However, black employees - and for this study, black engineers — do not attain at the same levels of career development as the white majority ${ }^{7,8,9}$. The purpose of this paper is to present the results of a study that explored career self-efficacy ${ }^{1}$ as a possible construct for understanding this gap between career opportunities and the career attainment of the black engineer. In social cognitive career theory, career self-efficacy is a key mediator of 
workplace performance ${ }^{10}$, and performance mediates attainment ${ }^{11}$. Therefore, understanding the current state of black engineer career self-efficacy may provide insight for future research and/or interventions in addressing this gap.

\section{The U.S. Engineering Field: Traditionally White}

Engineering has been a key component of the U.S.’s global technological superiority ${ }^{12,13}$. Today's U.S. engineering workforce is predominately white ${ }^{14,15}$, and the U.S. engineering career field has been described as a haven of "whiteness and masculinity", p.86, and as "pale" and "male"4,p.14. The current U.S. government engineering workforce reflects this same demographic $^{15}$.

The population of engineers in the U.S. workforce in 2008 was $1,582,000^{15}$. Whites, along with Asians, are overrepresented in engineering when compared to their proportion of the general U.S. population $^{14,15}$. Blacks and non-white Hispanics are underrepresented ${ }^{14,15,16,17}$, and their progress towards appropriate-equal to their percentage of the general population-

representation in the engineering field has been largely unchanged over the last 30 years ${ }^{15}$. For example, the percentage that black engineers make up in the workforce has remained steady at approximately $5 \%$ since the $1970 \mathrm{~s}^{8,15}$ and the total number of black engineers in the U.S. was only 49,000 in $2008^{15}$. Government black engineers make up approximately $10 \%$ of this total ${ }^{15}$.

\section{Changing Demographics and the Impact to the Engineering Workforce.}

The racial demographic of the U.S. is changing. According to a U.S. Census Bureau report ${ }^{18}$ the U.S. will be majority-minority by 2043, with a majority-minority workplace by 2060 . As part of this change in the U.S. racial demographic, both the number of white engineers currently in the workforce and the number of white engineers entering the workforce will also decrease ${ }^{19}$. Given current college and university graduation rates by race, the number of underrepresented minority engineers is not on a path to provide adequate representation and meet the expected shortfall $^{15}$. The current solution is to allow more foreign born engineers to enter the U.S. ${ }^{8,23}$. This in itself is not a negative. However, the disparity in income and wealth between underrepresented U.S. minorities and the majority could be addressed by higher incomes associated with engineering $^{24}$. It may be preferable to increase the percentage of U.S. citizens in this occupational field rather than filling the need through the hiring of non-U.S. citizens, an action that is not possible in some sectors ${ }^{25}$.

\section{Black Engineers as the Focus of the Study}

Both blacks and Hispanics are underrepresented in engineering ${ }^{15,20}$. However, for this study the focus was solely on black engineers. The basis of this delimiting was that the white majority sees blacks differently than Hispanics ${ }^{26,27,28}$, as well as the Blauner Hypothesis ${ }^{29}$. Hispanics are often preferred over blacks within their own organization. Additionally, blacks are more often perceived by whites as not wanting to work, whereas Hispanics are perceived to be more willing $^{26,28}$. Under the Blauner hypothesis, the disadvantaged status of involuntary immigrants persists longer than for those that voluntarily immigrate ${ }^{29}$. 


\section{Science, Technology, Engineering, and Mathematics (STEM)}

While the focus of this study was on the engineer in the workplace, it is important to recognize that a significant amount of attention has been given to minorities in engineering at the high school and college levels. This understanding is important for two reasons. The first is that it supports the overall need for studies on black engineers. Secondly, it indicates that the engineering workplace may have been understudied in the past. Attention to the recruitment and retention of underrepresented minorities in engineering is admirable, necessary, and well documented in literature ${ }^{3,8,21,22,30}$. Yet despite the emphasis on science and mathematics for underrepresented minority students in high school ${ }^{13,30,31}$, and retention activities in both historically black and predominantly white institutions ${ }^{32}$, the percentage of blacks in engineering has remained at a consistently low level for the past 30 to 40 years ${ }^{8,15}$. Underrepresentation in high school and college sets the context for the attainment gap and underrepresentation of the black engineer in the engineering workplace.

\section{Attainment}

Black engineers do not advance in their desired career paths, including management ranks, at the same rate as whites ${ }^{33}$. Tang notes that while minority "engineers may have overcome barriers in the education system, results...show that they have not achieved a comparable rate of success in the occupational system,,,p.201. In their desk reference on diversity, Gardenswartz and Rowe ${ }^{33}$ noted that there is an overall perception that things have gotten better- that blacks attain at the same levels as whites and that there is no business care for diversity. However, whites are much more likely to advance in their careers than underrepresented engineers; estimates range from $40 \%$ more likely to 13 times more likely, depending on the metric used $^{8,14,15,34,35}$.

Minorities make up a large percentage of lower level government employees, but their percentages decline significantly as they move towards higher level positions, in this case senior level positions within the U.S. government ${ }^{7}$. Blacks are $2 \frac{1}{2}$ times less likely to be in senior positions than whites ${ }^{7}$. The civilian components of the Department of the Army, Department of the Navy, and the Department of the Air Force occupy three of the bottom nine ratings on the Lieberson Index Diversity Score list ${ }^{7}$ — the bottom $25 \%$.

\section{Organizational Emphasis on Diversity}

These attainment and workplace environment issues exist despite the $\$ 8$ billion to $\$ 10$ billion companies spend annually on diversity programs to create opportunity and inclusion strategies for minority groups ${ }^{5,6}$, including black engineers. Organizations typically enter into diversity programs for one of two reasons: legal obligation or fairness ${ }^{4}$. There are many case studies of successful organizational diversity initiatives, and multi-organization case studies as well $^{13,45,48,49,50,51,52,53,54}$. Organizational diversity efforts may manifest themselves in training programs and employee feedback ${ }^{47}$; as components of performance evaluations, in the form of inclusion projects, as social networking, as the responsibility of management, in the form of mentoring systems, and in affinity groups ${ }^{45}$. 


\section{Purpose and Research Question}

The purpose of this quantitative survey research is to understand the career self-efficacy of the U.S. government black engineer. Given the low attainment levels of blacks in the workplace when compared to the white majority, the relationship of self-efficacy to performance and attainment, and the lack of career self-efficacy information on black engineers in the workplace, the following research question is warranted: "What is the current state of the career selfefficacy of the black engineer in the U.S. government workplace?"

\section{The Call for this Research}

A gap exists in the literature and in empirical knowledge around the career self-efficacy of the black engineer in the workplace. While providing a plethora of information on career development assessment and career counseling, nearly all related studies of career self-efficacy have occurred with college students and focus on the related topic of career decision-making self-efficacy $58,65,84,100,107,108,109,110$. Previous work also includes the development of the widely used Career Decision-making Self-efficacy (CDSE) scale ${ }^{87}$ and CDSE - Short Form (CDSE$\mathrm{SF})^{2}$ in these student-focused studies.

Career self-efficacy has been identified as a promising construct for future research ${ }^{74}$, specifically due to little research being conducted beyond college level subjects ${ }^{111,112}$. Research into career outcomes beyond the self-efficacy intentions of students is required ${ }^{31}$. Others call for studies on diverse populations and self-efficacy ${ }^{113}$, and on blacks and career self-efficacynoting that most of what we know about the CDSE-SF scale is from studies of white college students at Predominately White Institutions (PWI) ${ }^{114}$. Kochan, et al. ${ }^{6}$ call for the development of interventions to provide a positive link between diversity and performance. Most important to this research study on the career self-efficacy of black engineers is Nilsson, et al.'s recommendation that the CDSE and CDSE-SF be used on older persons - that is, beyond college—and on persons "of color"104,p.654.

\section{Theoretical and Conceptual Frameworks}

There exists a gap between the opportunities created as a result of organizational diversity programs - specifically engineering career attainment opportunities — and the attainment level of the black engineer in realizing these opportunities. What can organizations do to close this gap? Is there a way to better understand the gap at the individual level of analysis such that deliberate and intentional interventions could be executed by the organization and leadership at the organizational level? Is there a way to gather human resource data ${ }^{6}$ to assist in understanding the gap?

The following sections describe the results of a study on career self-efficacy ${ }^{1}$ to see if it provides insight into the gap. Both career self-efficacy and social cognitive career theory emerge from Albert Bandura's work in social cognitive theory (SCT) and self-efficacy. According to Bandura ${ }^{55,56}$ and SCT, individuals have control over the way that they think, feel, act, and motivate themselves. Performance is enhanced or impaired through motivation and $\operatorname{cognition}^{68}$. Behavior is regulated against reference standards which are based on interactions between the individual's self system and environmental influences ${ }^{55,58}$. According to SCT, 
individuals have control of their own cognitive processes and can take action to change their environment $^{55,58}$. If they believe that their behavior can affect a positive outcome, they are more likely to $\mathrm{act}^{58}$.

SCT is founded on the concept of reciprocal determinism, specifically the triadic reciprocal relationship of cognitive-personal-factors, behavior, and environmental factors. One's beliefs about his or herself have impact and influence on control and agency ${ }^{55,58,63}$. In SCT, a person's beliefs about their capabilities influence how they will behave more so than even their skills and previous accomplishments ${ }^{55,58}$. However, SCT does not presume that people can exceed their capabilities by some positive belief system ${ }^{55,58}$.

Self-efficacy originates in SCT as a method of determining how well knowledge and skills were acquired $^{58,60}$. Bandura defines self-efficacy as the "belief in one's capabilities to organize and execute the courses of action required to produce given attainments"56,p.3. Bandura's 1977 article $^{59}$ is considered the seminal work in self-efficacy theory. According to Bandura ${ }^{55,56,59,60 \text {, }}$ self-efficacy has four contributing sources: personal experience and mastery, vicarious learning through the experiences of others, verbal persuasion and acknowledgement of others, and the individual's physiological state. Personal mastery contributes the most to one's selfefficacy $^{55,56}$. Overall, self-efficacy beliefs influence how individuals behave and what actions they will take ${ }^{58,64}$. The greater an individual's self-efficacy in a given behavior domain, the more likely the individual is to undertake the task rather than to avoid it. Bandura has argued that assessing an individual's general self-efficacy is incorrect ${ }^{55,56}$. Rather, one must assess self-efficacy in its task specific behavior domain. For this study that domain is career path.

\section{$\underline{\text { Career Self-Efficacy }}$}

Hackett and Betz's ${ }^{1}$ article on a self-efficacy approach to the career development of women is recognized as the seminal work on career self-efficacy ${ }^{56}$. The model developed in Hackett and Betz's ${ }^{1}$ work postulated that socialization experiences caused low personal efficacy in women in relation to career related behaviors. This manifested itself in less than fully realized career pursuits ${ }^{1}$. The application of self-efficacy to career development has been seen as the most important use of Bandura's concept of self-efficacy ${ }^{70}$.

Studies of adult career self-efficacy are rare. Career self-efficacy, career decision self-efficacy, and career decision-making self-efficacy research has been widely conducted on high school and college students in STEM fields using intervention models ${ }^{13}$, to find career self-efficacy weaknesses prior to college ${ }^{330}$, in African-American's self-efficacy in traditional and nontraditional careers ${ }^{74}$, on African-American college students' career decisions ${ }^{75,76}$, on students' occupational self-efficacy $^{77}$, math and science self-efficacy ${ }^{78}$, persistence in college ${ }^{22}$, women in engineering programs ${ }^{79}$, on students' online career exploration ${ }^{80}$, on females at career fairs to determine the effect on their occupational self-efficacy ${ }^{81}$, on students' vocational identity and career exploration $^{82}$, on engineering design students ${ }^{83}$, to assess software engineering selfefficacy $^{84}$, with underprepared college students ${ }^{129}$, on students' science self-efficacy ${ }^{50}$, on black mathematics students ${ }^{62}$, on students' racial experiences ${ }^{130}$, and in conjunction with the Big Five Traits $^{73}$. Career self-efficacy has also been studied extensively in conjunction with career counseling interventions $^{85,86}$. Byars-Winston ${ }^{31}$ provides an extensive review of career decision self-efficacy research. 
Social Cognitive Career Theory

Social cognitive career theory (SCCT) is to SCT as career self-efficacy is to self-efficacy, a behavior domain specific application. SCCT brings together self-efficacy and attainment and their relationship to personal mastery; that is, past performance as shown in Figure 1.

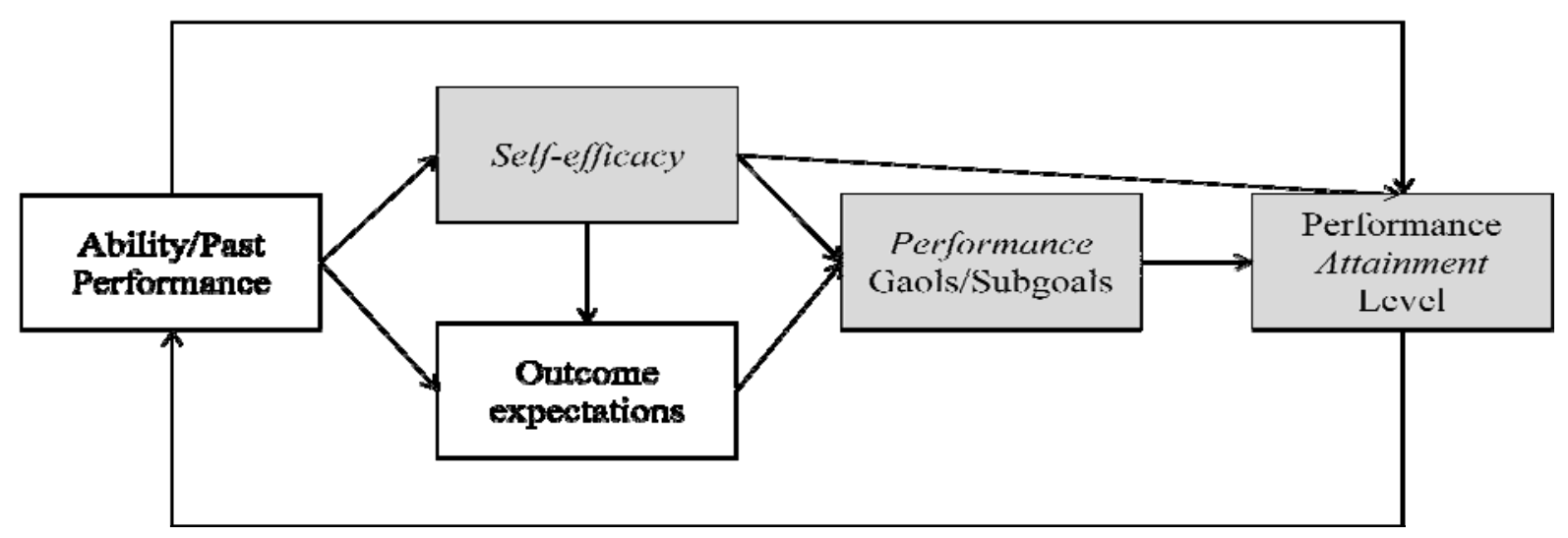

Figure 1. Lent, Brown, and Hackett's model of social cognitive theory ${ }^{11}$ with emphasis added

Lent, Brown, and Hackett present a social cognitive career development framework as a specific application of SCT based in Bandura's foundational works ${ }^{11}$. SCCT describes the elaboration and formation of career-related interests, how academic and career choice selections are made, and performance and persistence in occupational and educational pursuits. As with SCT, the focus is on the interaction between an individual's self-related thoughts and social processes that guide behavior; SCCT is also task situation specific, unlike more trait-oriented approaches to career development ${ }^{10}$. SCCT integrates career-related interest, career choice, and performance ${ }^{10}$ through the use of three models representing these elements. SCCT has been studied in computer career fields ${ }^{88}$; in areas outside of math and science such as art, social science, and English ${ }^{89}$; and in students' career choice ${ }^{90,91}$.

\section{Five Subscales of Career Self-efficacy}

Hackett and Betz's career self-efficacy subscales are based on Crites's Career Maturity Inventory (CMI) ${ }^{1}$. In its form at the time of Hackett and Betz's career self-efficacy work, CMI was composed of four dimensions ${ }^{92,93}$ : consistency of career choices, realism of career choice, career choice competencies, and career choice attitudes. Crites hypothesized in the career choice competencies portion of the inventory, and in conjunction with the attitudes portion of the inventory, that positive career decisions are enabled by competence in five career choice processes and by a mature attitude regarding the career choice process overall ${ }^{94}$. These five career choice processes are self-appraisal, occupational information gathering, goal setting, problem solving, and planning.

Self-Appraisal. Self-appraisal is an aspect of career self-efficacy and is demonstrated through one's assessment of their abilities, ideals, and values. Crites referred to this section of his competence test, a piece of the CMI, as knowing yourself ${ }^{95}$. According to Hansen in his review 
of the CMI, this portion of the test was based on the assumption that individuals who can appraise the career development of others are also good self-appraisers ${ }^{95}$.

Occupational Information Gathering. Crites described occupational information gathering as knowing about jobs $^{111}$. This portion of the inventory was similar to the Strong Vocational Interest Blank and the Kuder Occupational Interest Survey ${ }^{95}$.

Planning. Planning is an aspect of career self-efficacy and is demonstrated through one's ability to project into the future, define intermediate steps, and manage the process. Looking ahead $^{95}$ is Crites's description for planning. In this portion of the CMI, Crites had respondents arrange a sequence of career related events in the order necessary to reach a career goal.

Goal Setting. Goal setting is evidenced by personal goals that demonstrate intention to engage in an activity or produce a specific outcome ${ }^{131}$. Goal setting is an aspect of career self-efficacy and is demonstrated through one's ability to choose a job while matching skills and lifestyle preference. Crites described this competency as choosing a job. This portion of the CMI measures one's competency for choosing occupations for hypothetical individuals with given characteristics $^{95}$.

Problem Solving. Problem solving is an aspect of career self-efficacy and is demonstrated through one's ability to identify remedies and alternatives. With respect to a career, what should a person do? - the problem solving section of the $\mathrm{CMI}^{94}$ addressed this question. This part of the CMI was based on the assumption that increased maturity resulted in improved decision making and problem solving related to career decision making.

\section{Methodology and Research Design}

This study employed a nonexperimental correlational ${ }^{116,117}$ cross-sectional $^{118}$ survey design with data being collected at one point in time. The survey mode was internet-based, using the SurveyMonkey ${ }^{\circledR}$ tool. The survey contained several demographic questions, preceded by an adapted 25-question CDSE-SF Likert-type scale ${ }^{2}$. Demographic information included gender, age range, engineering degree field, race, alma mater type for undergraduate and graduate degrees as applicable, NSBE and black Greek letter organization (BGLO) affiliation, and highest degree level. Additional questions were contained in the survey, but are not presented in this paper.

\section{Career Self-efficacy Instrument}

A number of instruments, inventories and scales have been developed to measure self-efficacy ${ }^{2}$, 56,96,97,98,99,100,101,102,103,104. Taylor and Betz developed the Career Decision-Making Self-efficacy (CDMSE) scale ${ }^{87}$, later called the CDSE scale, based on Crite's career maturity theory ${ }^{66}$. The original 50-question scale was reduced to a 25-question CDSE-SF and validated ${ }^{2,71}$. The original CDSE scale ${ }^{87}$ was developed for use with college students to assess their belief in their capabilities to make career decisions or, according to Betz and Taylor, to "measure an individual's degree of belief that he/she can successfully complete tasks necessary to make career decisions",p.4. The CDSE captures five competencies associated with career decision making: self-appraisal, occupational information gathering, goal setting, planning, and problem 
solving. Responses were provided through a Likert-type 1-5 point scale and an associated word scale with five choices ranging from "No Confidence at All” to "Complete Confidence" for each question.

The first 25 questions of the survey used in this study were taken from the CDSE-SF ${ }^{2}$. Fifteen were adapted and 10 were used without alteration. The original CDSE and CDSE-SF scales were developed around the language of college students and their majors, and occupation selection. For this study, the CDSE-SF was adapted to reflect language associated with the workplace-for example, major to job.

Six scores were calculated from the 25-questions from the CDSE-SF, one total score and five subscale scores. The total score is the sum of all scores for one individual's responses divided by 25, providing a mean career self-efficacy score; the subscale scores are totaled according to the question grouping and each subscale score total is divided by five, producing a mean subscale score. The results produced a score that falls between the values of 1 and 5 and corresponded directly to the description of the point value in the survey. Betz, Klein, and Taylor ${ }^{2}$ suggested that a score of 3.5 or above-moderate to high confidence-be seen as a willingness to try the behavior in question and scores below 3.5 be seen as suggesting inadequate confidence approach behavior. This corresponds to high and low career self-efficacy respectively.

\section{Demographic Questions}

Demographic information was used to evaluate the representativeness of the sample and to contribute to the understanding of career self-efficacy. The first demographic question asked the gender of the participant, female or male. Age was asked in 10-year increments beginning with 29 years of age or younger through 70 years and older. Engineering degree field of the survey respondent was asked based on NSF categories ${ }^{15}$ with the addition of computer, nuclear and petroleum engineers as used in an earlier NSF engineering workforce study ${ }^{119}$. Although the survey was sent only to engineers that had previously self-selected as black, race was asked based on the NSF taxonomy ${ }^{15}$. The purpose of this question was, using skip logic, to send any unintended white respondents to the end of the survey and to allow any non-black engineer data to be removed prior to data analysis. Precautions were taken to reduce the possibility of nonblack participants receiving the survey by sending the invitation only to self-identified black engineers. The type of college or university from which the respondent received their undergraduate degree and graduate degrees, if applicable, was requested. College and university types were chosen based on general, yet encompassing, categories: PWIs and HBCUs ${ }^{32}$. The other category was provided in case the respondent wished to indicate a High Hispanic Enrollment institution $^{132}$, religious, or gender-specific alma mater. Affiliations status with a BGLO and NSBE was also asked.

\section{Sampling Plan}

Engineers in the U.S. were the target rather than the larger STEM population. There are 49,000 black engineers in the U.S. workplace ${ }^{15}$. However, in this study, the population of interest was black engineers employed by the U.S. government. The total size of this population was 4,653 in $2008^{15}$ or approximately $9.5 \%$ of the overall number of black engineers in the U.S. The surveyed site was a large U.S. government engineering organization with over 14,000 
employees, of which over 11,000 were engineers and scientists of all races, and over 500 were black engineers. All engineers within the sampling frame were surveyed, constituting a convenience sample ${ }^{116,117}$. The sample did represent a geographically dispersed organization, however.

\section{Survey Instrument Validity and Reliability}

Validity must be given the highest priority when using a survey instrument ${ }^{116}$. The 25-question CDSE-SF has shown itself to be as valid and reliable as the longer 50 -question form ${ }^{2,114}$. Given that self-efficacy is a domain specific construct ${ }^{56}$, it is important that the CDSE-SF be used in a career choice context, supporting "content-related evidence of validity"116,p.150. The CDSE instrument was developed from Crites's ${ }^{94}$ theory of career maturity, which describes five competencies associated with career choice. These five are the subscale factors used in the CDSE-SF. Internal validity was supported by collecting age range, gender, engineering degree field, degree level, and alma mater data. Race, career field — engineers, and sectorgovernment employees, were all variables being controlled. Generalizability of the results of this study from black engineers in the U.S. government to all black engineers was also a threat to external validity. Hence, no suggestion of generalizability outside the U.S. government engineers is made, nor is any suggestion of ecological generalizability made ${ }^{116}$. Construct validity was applicable to this research design, as the construct of career self-efficacy cannot be measured directly. Mono-operation bias was a threat to construct validity ${ }^{120,121}$. However, using an established scale reduced the risk of not adequately measuring the focal construct. The researcher claims that the CDSE-SF corresponded to the concept of career self-efficacy based on the "extensive evidence for validity",2, specifically in the areas of content validity, factor structure, and criterion-related validity. The five subscales have also been shown to be valid $^{114,122}$.

The CDSE 50-question form developed by Taylor and Betz ${ }^{87}$ from which the CDSE-SF was derived was first tested on 346 students, resulting in a Cronbach's alpha of .86 to .89 for the subscales, and .97 for the total scale. Other studies have shown high Cronbach's alphas as well $^{67,71,100,104,114,123,124,125}$.

\section{Data Collection and Results}

The primary method of data collection was the internet survey using the SurveyMonkey tool. This tool provided an internet address at which the participant could access the survey. An initial e-mail invitation containing this link was sent to the e-mail addresses of 524 black engineers within the surveyed organization. Surveys were delivered and responses were received over a 27-day time period. The data was analyzed and the research question was addressed.

\section{$\underline{\text { Response Rate }}$}

The overall response rate to the survey was $29.3 \%$ or 154 responses, with $37.6 \%$ of that total coming within the first 24-hours after the initial e-mail invitation was sent. Over half of the responses—-52.6\% —-were received in response to the invitation e-mail; 33.1\% were received in 
response to the first follow-up e-mail, and the remainder in response to the second follow-up email.

\section{$\underline{\text { Preparation for Data Analysis }}$}

The data was downloaded from SurveyMonkey in SPSS format and processed in SPSS version 21. Nineteen records were deleted based on significant gaps in the data created when the respondents exited the survey early - a dropout rate of $12.3 \%$ compared to an expected dropout rate for a 45 -question survey of $11 \%{ }^{128}$. Four records were removed due to race selection: one each for white and multi-race, and two for Hispanic. While Hispanics could self-select as black, the survey was sent to engineers who had previously self-selected as black. In keeping with the intent of the survey, these records were deleted. One hundred thirty-one usable records remained.

\section{Career Self-efficacy}

The first 25 questions dealt with career self-efficacy. Descriptive statistics for these questions are provided in Table 1. While question 10 (Q10) responses resulted in a score of 3.52 only Q13 and Q17 fell below 3.5, the lower limit of the high score range ${ }^{87}$. Cronbach's alpha for the career self-efficacy questions was .96. The data provided in response to the career self-efficacy questions is reliable and consistent.

\section{Demographics: Representativeness of the Sample}

Responses to demographic questions are compared in Table 2 to the expected values. Though gender did not emerge as significant in the subsequent data analysis, the distribution of female and male respondents was different than expected. The engineering degree field distribution of the respondents is also different from that reported by the NSF for government engineers ${ }^{2}$. Although this did not affect answering the research question, it is likely attributable to the specific mission of this government engineering organization being a subset of all engineers aggregated by the NSF, as well as the Other category being quite large and unexplained in the NSF data ${ }^{15}$.

NSBE membership declines with age; this correlation was significant at $\alpha=.01(r=.240, p=$ .006, 2-tailed). NSBE membership drops off sharply in the 40-49 years of age range. NSBE membership increases as degree level increases; this was significant at $\alpha=.05(r=-.192, p=$ .029, 2-tailed). BGLO membership was positively correlated with NSBE membership at $\alpha=$ .05 ( $r=.196, p=.025$, 2-tailed). As with NSBE, BGLO membership affiliation increased with higher degree attainment; this correlation was significant at $\alpha=.05$ ( $r=-.192, p=.029$, 2tailed). There was a statistically significant correlation, $\alpha=.01$, between undergraduate alma mater and graduate degree alma mater ( $r=.332, p=.001$, 2-tailed). A respondent was more likely to have attended an HBCU for their undergraduate degree if they attended an HBCU for their graduate degree. Male respondents were more likely $(\alpha=.05)$ to have attended an HBCU for their masters degree or doctorate than women $(r=.254, p=.016$, 2-tailed). Seven of the 51 male respondents had attended an HBCU for their advanced degree, while all of the 39 female respondents with advanced degrees attended non-HBCUs. 
Table 1. Descriptive Statistics for Career Self-efficacy questions

\begin{tabular}{|c|c|c|c|c|c|c|}
\hline Qu. & How much confidence do you have & $N$ & $M$ & sd & Min & Max \\
\hline 1 & $\begin{array}{l}\text { That you can use the internet to find information } \\
\text { about jobs that interest you? }\end{array}$ & 131 & 4.19 & 0.878 & 2 & 5 \\
\hline 2 & $\begin{array}{l}\text { That you can select one job from a list of potential } \\
\text { jobs you are considering? }\end{array}$ & 131 & 4.08 & 0.953 & 1 & 5 \\
\hline 3 & $\begin{array}{l}\text { That you can make a plan of your goals for the next } \\
\text { five years? }\end{array}$ & 131 & 4.09 & 0.948 & 2 & 5 \\
\hline 4 & $\begin{array}{l}\text { That you can determine the steps to take if you are } \\
\text { having trouble with an aspect of your job? }\end{array}$ & 131 & 3.88 & 0.969 & 1 & 5 \\
\hline 5 & That you can accurately assess your abilities? & 130 & 4.12 & 0.726 & 2 & 5 \\
\hline 6 & $\begin{array}{l}\text { That you can select one job from a list of potential } \\
\text { jobs you are considering? }\end{array}$ & 130 & 4.16 & 0.913 & 2 & 5 \\
\hline 7 & $\begin{array}{l}\text { That you can determine the steps you need to take to } \\
\text { successfully change jobs? }\end{array}$ & 131 & 3.89 & 0.914 & 2 & 5 \\
\hline 8 & $\begin{array}{l}\text { That you can persistently work at your career goal(s) } \\
\text { even when you get frustrated? }\end{array}$ & 131 & 4.15 & 0.836 & 2 & 5 \\
\hline 9 & $\begin{array}{l}\text { That you can determine what your ideal job would } \\
\text { be? }\end{array}$ & 131 & 3.91 & 0.898 & 2 & 5 \\
\hline 10 & $\begin{array}{l}\text { That you can find out the employment trends for } \\
\text { engineering in the next decade? }\end{array}$ & 131 & 3.52 & 0.889 & 1 & 5 \\
\hline 11 & $\begin{array}{l}\text { That you can choose a job that will fit your preferred } \\
\text { lifestyle? }\end{array}$ & 131 & 3.73 & 0.951 & 1 & 5 \\
\hline 12 & That you can prepare a good resume? & 131 & 4.12 & 0.794 & 2 & 5 \\
\hline 13 & $\begin{array}{l}\text { That you can change jobs if you do not like your } \\
\text { current one? }\end{array}$ & 131 & 3.39 & 1.071 & 1 & 5 \\
\hline 14 & That you can decide what you value most in a job? & 130 & 4.18 & 0.849 & 2 & 5 \\
\hline 15 & $\begin{array}{l}\text { That you can find out about the average yearly } \\
\text { earnings of people in engineering? }\end{array}$ & 131 & 4.00 & 0.945 & 1 & 5 \\
\hline 16 & $\begin{array}{l}\text { That you can make a career decision and then not } \\
\text { worry whether it was right or wrong? }\end{array}$ & 131 & 3.56 & 0.970 & 1 & 5 \\
\hline 17 & $\begin{array}{l}\text { That you can change jobs if you are not satisfied with } \\
\text { your current one? }\end{array}$ & 131 & 3.43 & 1.031 & 1 & 5 \\
\hline 18 & $\begin{array}{l}\text { That you can figure out what you are and are not } \\
\text { ready to sacrifice to achieve your career goals? }\end{array}$ & 129 & 4.06 & 0.817 & 2 & 5 \\
\hline 19 & $\begin{array}{l}\text { That you can talk with a person already employed in } \\
\text { the type of job you are interested in? }\end{array}$ & 131 & 3.82 & 0.924 & 2 & 5 \\
\hline 20 & $\begin{array}{l}\text { That you can choose a job that will suit your } \\
\text { abilities? }\end{array}$ & 131 & 3.89 & 0.950 & 1 & 5 \\
\hline 21 & $\begin{array}{l}\text { That you can identify employers, firms, and } \\
\text { institutions relevant to your career possibilities? }\end{array}$ & 131 & 3.92 & 0.804 & 2 & 5 \\
\hline 22 & $\begin{array}{l}\text { That you can define the type of lifestyle you would } \\
\text { like to live? }\end{array}$ & 130 & 4.31 & 0.703 & 3 & 5 \\
\hline 23 & $\begin{array}{l}\text { That you can find information about graduate or } \\
\text { professional schools? }\end{array}$ & 130 & 4.52 & 0.673 & 2 & 5 \\
\hline 24 & $\begin{array}{l}\text { That you can successfully manage the job interview } \\
\text { process? }\end{array}$ & 131 & 4.12 & 0.794 & 2 & 5 \\
\hline 25 & $\begin{array}{l}\text { That you can identify some reasonable job } \\
\text { alternatives if you are unable to get the job you want? }\end{array}$ & 131 & 3.79 & 0.877 & 2 & 5 \\
\hline
\end{tabular}


Table 2. Survey representativeness of demographic variables, $N=131$

\begin{tabular}{|c|c|c|c|c|c|}
\hline $\begin{array}{c}\text { Demographic } \\
\text { Variable }\end{array}$ & Demographic & $\begin{array}{l}\text { Expected }^{\mathrm{a}} \\
\text { Value }\end{array}$ & Source & $N$ & $\begin{array}{c}\text { Survey }^{\mathrm{b}} \\
\text { Result }\end{array}$ \\
\hline Gender & $\begin{array}{l}\text { Female } \\
\text { Male }\end{array}$ & $\begin{array}{l}29 \% \\
71 \%\end{array}$ & NSF (2012) & $\begin{array}{l}53 \\
78\end{array}$ & $\begin{array}{l}40.5 \% \\
59.5 \%\end{array}$ \\
\hline Age & $\begin{array}{l}29 \text { or less } \\
\text { Between 30-39 } \\
\text { Between } 40-49 \\
\text { Between 50-59 } \\
60 \text { or over }\end{array}$ & $\begin{array}{c}14 \% \\
32 \% \\
29 \% \\
18 \% \\
7 \%\end{array}$ & $\begin{array}{l}\text { Parker } \\
(2004)\end{array}$ & $\begin{array}{c}11 \\
42 \\
36 \\
35 \\
7\end{array}$ & $\begin{array}{c}8.4 \% \\
32.1 \% \\
27.5 \% \\
26.7 \% \\
5.3 \%\end{array}$ \\
\hline $\begin{array}{l}\text { Engineering } \\
\text { field }\end{array}$ & $\begin{array}{l}\text { Aerospace } \\
\text { Chemical } \\
\text { Civil } \\
\text { Electrical, electronics, } \\
\text { computer science } \\
\text { Industrial } \\
\text { Mechanical } \\
\text { Other, including } \\
\text { Nuclear and Petroleum }\end{array}$ & $\begin{array}{c}8 \% \\
1 \% \\
9 \% \\
34 \% \\
\\
3 \% \\
8 \% \\
36 \%\end{array}$ & $\begin{array}{l}\text { Carnevale, } \\
\text { et al. } \\
\text { (2012); } \\
\text { NSF (2012) }\end{array}$ & $\begin{array}{c}3 \\
7 \\
4 \\
55 \\
\\
\\
17 \\
35 \\
10\end{array}$ & $\begin{array}{c}2.3 \% \\
5.3 \% \\
3.1 \% \\
42.0 \% \\
\\
13.0 \% \\
26.7 \% \\
7.6 \%\end{array}$ \\
\hline $\begin{array}{l}\text { HBCU/non- } \\
\text { HBCU } \\
\text { (undergraduate) }\end{array}$ & $\begin{array}{l}\text { HBCU } \\
\text { Non-HBCU }\end{array}$ & $\begin{array}{l}31 \% \\
69 \%\end{array}$ & $\begin{array}{l}\text { Culotta } \\
(1992)\end{array}$ & $\begin{array}{l}43 \\
88\end{array}$ & $\begin{array}{l}32.8 \% \\
67.2 \%\end{array}$ \\
\hline Degree level & $\begin{array}{l}\text { Bachelors } \\
\text { Masters } \\
\text { Doctorate }\end{array}$ & $\begin{array}{c}69 \% \\
27 \% \\
4 \%\end{array}$ & NSF (2012) & $\begin{array}{l}35 \\
82 \\
12\end{array}$ & $\begin{array}{c}27 \% \\
64 \% \\
9 \%\end{array}$ \\
\hline $\begin{array}{l}\text { HBCU/non- } \\
\text { HBCU } \\
\text { (graduate) }\end{array}$ & $\begin{array}{l}\text { HBCU } \\
\text { Non-HBCU }\end{array}$ & -- & -- & $\begin{array}{c}7 \\
83\end{array}$ & $\begin{array}{c}7.2 \% \\
92.8 \%\end{array}$ \\
\hline $\begin{array}{l}\text { NSBE } \\
\text { membership }\end{array}$ & $\begin{array}{l}\text { No } \\
\text { Yes }\end{array}$ & $\begin{array}{l}84 \% \\
16 \%\end{array}$ & $\begin{array}{l}\text { NSBE } \\
\text { (2013) }\end{array}$ & $\begin{array}{l}95 \\
36\end{array}$ & $\begin{array}{l}72.5 \% \\
27.5 \%\end{array}$ \\
\hline $\begin{array}{l}\text { BGLO } \\
\text { membership }\end{array}$ & $\begin{array}{l}\text { No } \\
\text { Yes }\end{array}$ & -- & -- & $\begin{array}{l}95 \\
36\end{array}$ & $\begin{array}{l}72.5 \% \\
27.5 \%\end{array}$ \\
\hline
\end{tabular}

${ }^{\mathrm{a}}$ Based on data as indicated in the source column. A dashed line in the expected value column indicates that no data was cited.

${ }^{b}$ Reflects the percentage of respondents from the surveyed organization, a subset of all black engineers in the U.S. government.

\section{Answering the Research Question}

The research question was "What is the current state of the career self-efficacy of the black engineer in the U.S. government workplace?” From the descriptive statistical data provided in 
Table 1, it is clear that the overall career self-efficacy of the black engineer is high. The mean overall career self-efficacy total score was 3.95, with a standard deviation of 0.638 , across all respondents, with individual respondents ranging from 2.33 to the maximum score of 5 . Betz and Taylor suggest that any score above 3.5 represents high career self-efficacy ${ }^{87}$.

As a reminder, career self-efficacy consists of five subscales: self-appraisal, occupational information gathering, goal setting, planning, and problem solving ${ }^{1}$. In all cases, the subscale scores of black engineers are higher than 3.5, with the lowest being problem solving at 3.73, as shown in Table 3.

Table 3. Career self-efficacy subscale scores, $N=131$

\begin{tabular}{lccccc}
\hline CSE Scores & Questions & $M$ & $S D$ & Min & Max \\
\hline Total Score & (all) & 3.95 & 0.639 & 2.33 & 5.00 \\
Self-Appraisal & $5,9,14,18,22$ & 4.11 & 0.644 & 2.60 & 5.00 \\
Occupational Information Gathering & $1,10,15,19,23$ & 4.01 & 0.625 & 2.60 & 5.00 \\
Goal Setting & $2,6,11,16,20$ & 3.88 & 0.770 & 1.40 & 5.00 \\
Planning & $3,7,12,21,24$ & 4.03 & 0.677 & 2.40 & 5.00 \\
Problem Solving & $4,8,13,17,25$ & 3.73 & 0.794 & 1.80 & 5.00 \\
\hline
\end{tabular}

Other than age ( $r=-.157, p=.074$, 2-tailed), there were no statistically significant differences near or below the prescribed level $(\alpha=.05)$ for total career self-efficacy scores of the demographic variables. For relationships between the subscale scores and the demographic variables, only two statistically significant relationships were discovered, both at $\alpha=.05$. One was a relationship between the planning subscale and the age of the respondent $(r=-.183, p=$ .036, 2-tailed) and the other was between the occupational information gathering subscale and whether or not the respondent had attended an HBCU for their graduate degree $(\mathrm{r}=-.217, \mathrm{p}=$ .040, 2-tailed). Planning subscale scores declined with age and the occupational information gathering subscale was higher for those attending non-HBCUs for their graduate degrees.

\section{Limitations}

As with any study, limitations exist. The following sections document limitations concerning generalizability, the CDSE-SF tool itself, the lack of comparative information for other racial groups, and response rate.

\section{Generalizability}

The researcher makes the claim that the 131 black engineers surveyed are representative of the 524 black engineers within the organization, producing a valid study. Gender and undergraduate alma mater ratios were as expected. The age distribution for black engineers in the surveyed organization was not available to the researcher, but the age distribution did match the distribution of black engineers within the U.S. government. Engineering field was difficult to compare; but where comparable in fields such as electrical, mechanical, computer, and industrial engineering, showed strong similarities. The degree level of those responding to the 
survey was higher than for all STEM fields in the surveyed organization, but specific engineering-only distribution with the organization was unavailable.

While the researcher would also like to claim generalizability across all black engineers in the U.S. government, this is likely not possible. The surveyed organization's black engineering population makes up over $9 \%$ of all black engineers in the U.S. government and the demographic data of those responding compares favorably to the demographics of all black engineers in the U.S. government for age and for undergraduate alma mater. However, this comparison cannot be made for gender, engineering field and degree level. One also has to consider that those surveyed are employed by a large DoD engineering operation, but that not all U.S. government engineers are employed in a workplace with such a high density of engineers. While the lack of generalizability to all black engineers in the U.S. government is not claimed, data from this study lays the groundwork for future efforts that will continue to build in this area.

\section{$\underline{\text { CDSE-SF as a Tool }}$}

The findings show that the career self-efficacy of U.S. government black engineers, as measured by the CDSE-SF, is very high. The results compare well with previous studies of high school and college students, and provide valuable data to better understand career selfefficacy in the workplace.

However, as this tool has largely been used on student populations, it may need further evaluation and validation in a workplace environment. This is not to suggest that the CDSE-SF is not a reliable and valid instrument; this study was the first time that the adapted CDSE-SF questionnaire had been tested. Rather, it is unknown whether its questions may still be too specific to the language and context of college students. The intentionally minimal adaptations made by the researcher to the instrument for this study may not adequately convey a change in context. What is known is that the CDSE-SF showed a high Cronbach's alpha of .96, continuing its tradition of reliable assessments.

However, the most significant challenge to internal validity may be the way the survey was perceived by the respondents ${ }^{127}$. Feedback provided to the researcher by survey respondents indicated that the survey was overly simplistic. One respondent e-mailed that "I'm not sure of any engineers who would have a hard time doing anything you listed in the questions." With that said, there were still overall career self-efficacy scores as low as 2.33.

The consequences of using the CDSE-SF could include concluding that the career self-efficacy of the black engineer in the U.S. government is higher than it actually is. This could then be used to support that everything is okay in the workplace ${ }^{33,106}$ with respect to career self-efficacy and the black engineer.

\section{Comparison to Whites, Hispanics, and Asians}

This study was not comparative. Career self-efficacy scores of other minorities or the white majority within the surveyed organization were not collected. Career self-efficacy research has rarely left the confines of high school and college. For the data available from those domains, 
the results of this study compared favorably. Betz, et al. ${ }^{71}$ and Chaney, et al. ${ }^{114}$ provide a racial comparison of college students' scores. In the Betz study, blacks and Hispanics had higher career self-efficacy than whites and Asians. Chaney, making comparison to the whites in the Betz study, found higher career self-efficacy scores for black students. Conversely, Gloria and Hird $^{69}$ found higher scores for whites than nonwhites using the CDSE-SF in their study. Gecas $^{68}$ reported a number of studies performed in the 1970s showing lower self-efficacy for blacks, but he attributed this to the effects of racial discrimination. More data is needed on career self-efficacy in the workplace.

\section{Low Response Rate}

One of the limitations of the survey was the response rate and any impact that rate may have had on the study's findings. The response rate was lower than the researcher had anticipated. Based on the literature, a 30\% response rate was expected from the invitation e-mail alone ${ }^{126}$. The response rate for this study, at 29.3\%, was slightly less than that after both follow-up contacts. The researcher also believed that the specific topic ${ }^{127}$ related to black engineers being sent to black engineers would increase the response rate. This was not the case.

\section{Interpretation and Conclusions}

Overall, the research indicates that the career self-efficacy of black engineers in the organization surveyed is high both for the total score and for the subscale scores. The researcher concludes that career self-efficacy is a means of understanding the gap between attainment and opportunity. This was evidenced in the data acquired through this research.

The model representing the knowledge of one's career self-efficacy assists in assessing the gap between attainment and opportunity as first shown in Figure 1 is adapted in Figure 2. The latter figure is modified with an overlay of the sources of self-efficacy ${ }^{55,56,59,60}$, the five subscales of career self-efficacy ${ }^{1}$, the subscale scores from this study, and a block representing opportunity and generating the resulting gap. In SCCT, self-efficacy leads to performance and attainment ${ }^{11}$, and also influences outcome expectations. Considering the model shown in Figure 2, human resource data exists in most U.S. government organizations to document an individual's abilities and past performance through resumes and training records, their performance goals through performance appraisal systems, and certainly their attainment level through their current position documentation ${ }^{70,72}$. By assessing career self-efficacy, a key piece of information is added to the model. In fact, with respect to the model this leaves only outcome expectations as unknown in the typical U.S. government workplace.

From the research conducted in this study, it can be seen that the self-efficacy of the black engineers in the surveyed organization is high. While the specific nature of the gap between attainment and opportunity in this organization was not known, there was feedback from the open-ended questions to suggest that the gap does exist. Furthermore, it is known that the Lieberson Diversity Index ${ }^{7}$ ranks components of the DoD at the bottom of the index for the three highest government pay classifications: GS-14, GS-15, and Senior Executive Service positions. For the surveyed organization, career self-efficacy provides information into the SCCT and ultimately into the gap. As noted, this leaves outcome expectations as an unknown. 


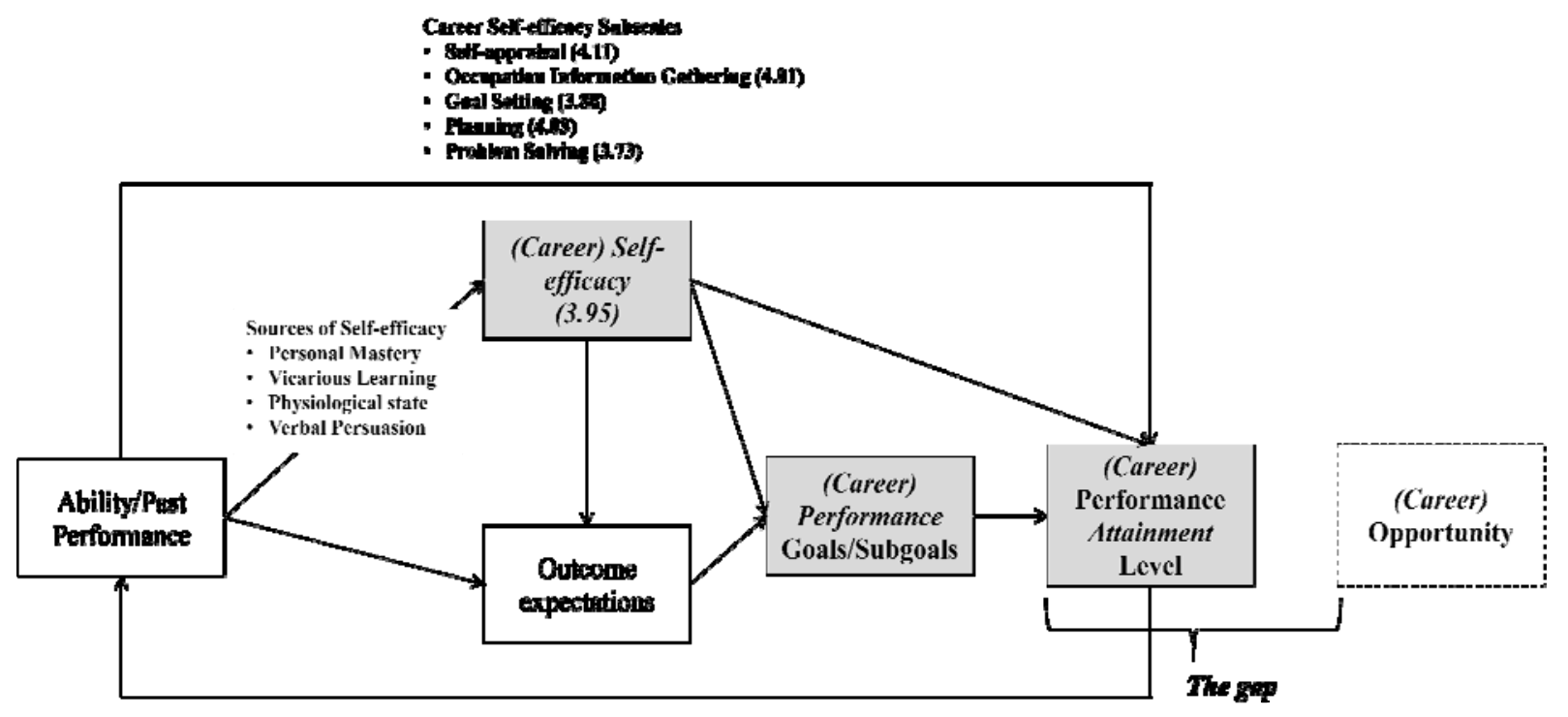

Figure 2. Lent, et al.'s model ${ }^{11}$ of SCCT along with the four sources of self-efficacy ${ }^{56,58,59,60}$, the five career self-efficacy subscales ${ }^{1}$, subscale scores from this research, and a block representing opportunity and the resultant gap between it and attainment.

Although not a focus of this research, career outcome expectations are directly influenced by career self-efficacy according to SCCT. Bandura ${ }^{55}$ was clear that one's judgment of selfefficacy is not the same as one's judgment of expected outcomes, but rather outcome expectations are influenced by self-efficacy. High self-efficacy should have a positive influence on outcome expectations. Outcome expectations are also influenced by context ${ }^{10}$. This leads to a bigger component of social cognitive theory that is not addressed directly by SCCT, the environment. The environmental context influences every component of the SCCT model; thus, it has a significant impact on the gap between attainment and opportunity in the workplace.

Black engineering graduates find employment in majority engineering workplaces where they are less likely to advance than their white counterparts $8,34,36,37$. As part of this workplace environment, they are also subject to homosocial reproduction ${ }^{38,39}$, nepotism ${ }^{34}$, and cronyism ${ }^{34}$; experience structural, social and occupational segregation, as well as subtle forms of racism ${ }^{9,40}$; are drawn to homophilic relationships ${ }^{41}$; suffer from stereotype threat ${ }^{32}$; and deal with spatial segregation $^{37}$ and bias ${ }^{42,43}$. Even skin tone ${ }^{44}$ can have a negative impact on how one is received.

SCT, from which SCCT derives, is founded on the concept of reciprocal determinism, specifically the triadic reciprocal relationship of cognitive-personal-factors, behavior, and environmental factors. One's beliefs about his or herself have impact and influence on control and agency ${ }^{55,58,63}$. According to Bandura ${ }^{55,56}$ and SCT, individuals have control over the way that they think, feel, act and motivate themselves. Performance is enhanced or impaired through motivation and cognition ${ }^{57}$. Behavior is regulated against reference standards which are based on interactions between the individual's self system and environmental influences $^{55,58,63}$ as shown in Figure 3. According to SCT, individuals have control over their 


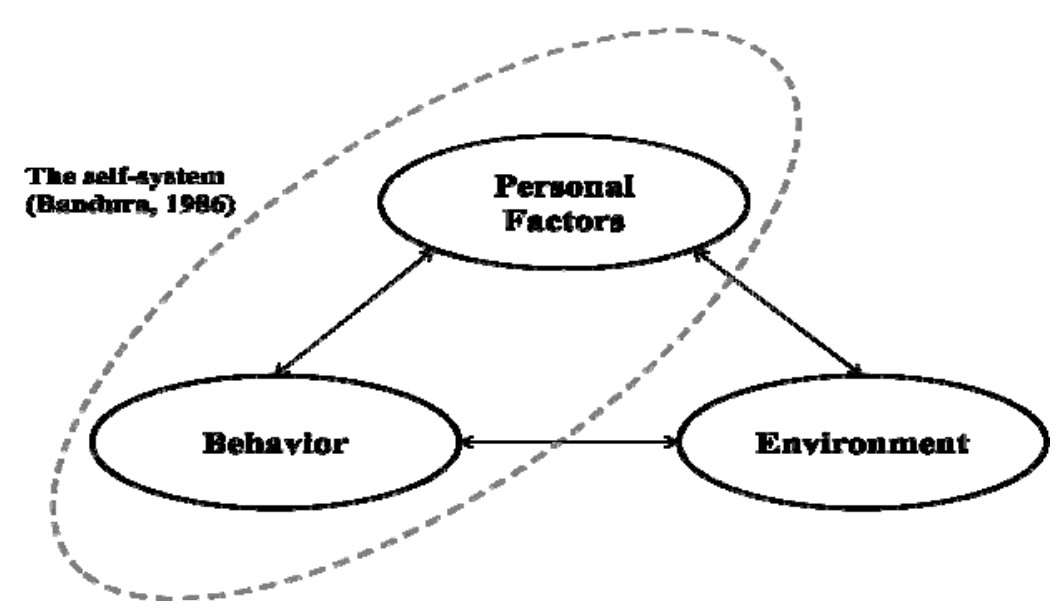

Figure 3. Social cognitive theory with distinction between the self-system and the environment.

own cognitive processes and can take action to change their environment ${ }^{55,58}$. If they believe that their behavior can affect a positive outcome, they are more likely to act ${ }^{56}$.

\section{Recommendations}

The researcher makes a number of recommendations as a result of this study. While the study focused on black engineers, the overall focus should remain on all underrepresented minority engineers with respect to race and gender. Career self-efficacy and the tools to measure it should be more strongly updated for workplace use. Outcome expectations, another mediator of performance in SCCT, should also be further explored.

\section{Expansion to all Underrepresented Minorities}

This research narrowed the population of interest from all underrepresented minorities to only black engineers with respect to the study of career self-efficacy and interracial workplace friendships. To address the projected crisis of 2060, future efforts must continue to address female, black, and Hispanic engineers as underrepresented minorities, as well as subgroups of overrepresented minorities. However, it should not be forgotten that the literature suggests that each of these minority groups is perceived and enacted differently by the majority ${ }^{26}$. This may require unique and specific instruments, interventions, and intentionalities ${ }^{105}$. Additionally, for comparative purposes as well as for the gathering of human resource data, expansion into the white majority and overrepresented minorities in engineering should be undertaken.

\section{Career Self-efficacy in the Workplace}

Career self-efficacy is clearly a powerful concept and has been noted as one of the most important domain-specific applications of self-efficacy ${ }^{56}$. Career self-efficacy encompasses career decision-making and career decision research ${ }^{71}$. It was developed as an abstract concept to group different career-related entities ${ }^{112}$ and has its roots in career counseling. To deliberately expand career self-efficacy from its high school and college level focus may require tailoring the career self-efficacy concept to be more specific to a career professional as she or he navigates a path to career attainment in the workplace. This would require further testing of 
adapted CDSE-SF type tools, and continued refinement and feedback loops. Career selfefficacy has proven beneficial in college career decision-making. It can also be of benefit in workplace career attainment. Several references support the call for the study of career selfefficacy beyond students ${ }^{31,74,111,112,114,115}$, but do not propose an alternate instrument beyond the 50- or 25-question versions of the CDSE.

\section{Evolve/adapt a Career Self-efficacy Tool}

Based on this call, it may be beneficial to further enhance and refine the CDSE-SF scale. Specifically, it is recommended that the scale be updated by subject matter experts and academic scholars to better report workplace content, as domain-specific scales of self-efficacy are more effective when tailored to the domain ${ }^{98,112}$. The adaptations for this study were kept at a minimal level so as to not impact the reliability of the instrument. Given the extent of the feedback, it appears that it may be necessary to further refine the scale to deliver data that allows for more insight. During this evaluation period, and perhaps beyond, it may be beneficial to capture more of the environmental aspects of the workplace with which to then compare the career self-efficacy data.

\section{Explore Outcome Expectations}

Although not a focus of this research, career outcome expectations are directly influenced by career self-efficacy according to SCCT. Bandura ${ }^{55}$ was clear that one's judgment of selfefficacy is not the same as one's judgment of expected outcomes, but rather outcome expectations are influenced by self-efficacy. High self-efficacy should have a positive influence on outcome expectations. Outcome expectations are also influenced by context ${ }^{10}$. This leads to a bigger component of social cognitive theory that is not addressed directly by SCCT, the environment. The environmental context influences every component of the SCCT model; thus, it has a significant impact on the gap between attainment and opportunity in the workplace.

\section{Final Thoughts}

It is the researcher's conclusion that career self-efficacy is a concept that can be used in the workplace to help address the gap between opportunity and attainment for black engineers, thus benefiting the organization. However, as most of the research associated with career selfefficacy has been associated with college students, it is time to further evolve the concept in the workplace. This may require additional research on updated subscales, and the development and testing of new instruments. The lineage of career self-efficacy, from Bandura to Betz, Byars-Winston, Borgen, Hackett, Lent, Taylor and others is strong. Migration of career selfefficacy to encompass more aspects of personal control over barriers in the workplace, social integration into workplace networks, relationship with coworkers, and environmental factors may be the next logical step. 


\section{References}

1. Hackett, G. \& Betz, N.E. (1981). A self-efficacy approach to the career development of women. Journal of Vocational Behavior, 18, 326-339.

2. $\quad$ Betz, N.E., Klein, K.L., \& Taylor, K.M. (1996). Evaluation of a short form of the career decision-making self-efficacy scale. Journal of Career Assessment, 4(1), 47-57.

3. Burack, C. \& Franks, S.E. (2004). Telling stories about engineering: Group dynamics and resistance to diversity. NWSA Journal, 16(1), 79-95.

4. Wulf, W.A. (1999). Diversity in engineering. Proceedings of the Moving Beyond Individual Programs to Systemic Change, WEPAN Annual Conference. West Lafayette, IN: WEPAN Member Services.

5. Hansen, F. (2003). Diversity’s business case doesn’t add up. Workforce, 82(4), $28-32$.

6. $\quad$ Kochan, T., Bezrukova, Ely, R., Jackson, S., Joshi, A., Jehn, K., Leonard, J., Levine, D., \& Thomas, D. (2003). The effects of diversity on business performance: Report of the diversity research network. Human Resource Management, 42(1), 3-21.

7. Starks, G.L. (2009). Minority representation in senior positions in U.S. federal agencies: A paradox of underrepresentation. Public Personnel Management, 38(1), 79-90.

8. Tang, J. (2000). Doing engineering. Lanham, MD: Rowman \& Littlefield.

9. Thomas, K.M. (2005). Diversity dynamics in the workplace. Belmont, CA: Wadsworth.

10. Lent, R.W., Brown, S.D., \& Hackett, G. (2002). Social cognitive career theory. In D. Brown \& Associates

11. Lent, R.W., Brown, S.D., \& Hackett, G. (1994). Toward a unifying social cognitive theory of career and academic interest, choice, and performance. Journal of Vocational Behavior, 45, 79-122.

12. Rogers, T.L. \& Houston, P.D. (2006). The other national security issue. School Administrator, 63(6), 5863.

13. Tsui, L. (2007). Effective strategies to increase diversity in STEM fields: A review of the research literature. The Journal of Negro Education, 76(4), 555-581.

14. Falkenheim, J.C. \& Burrelli, J.S. (2012). Diversity in science and engineering employment in industry. InfoBrief, NSF 12-311, 1-6. National Center for Science and Engineering Statistics.

15. National Science Foundation, (2012). Women, Minorities, and Persons with Disabilities in Science and Engineering: 2013, Washington, DC.

16. Frehill, L.M., DiFabio, N.M., Hill, S.T. (2008). Confronting the new American dilemma: Underrepresented minorities in engineering: A data-based look at diversity. National Action Council for Minorities in Engineering. Retrieved September 13, 2013 from http://www.nacme.org/user/docs/NACME\%2008\%20ResearchReport.pdf

17. Lewis, J.L., Menzies, H., Najera, E.I., \& Page, R.N. (2009). Rethinking trends in minority participation in the sciences. Science Education, 93, 961-977. Published online 27 March 2009 in Wiley InterScience (www.interscience.wiley.com). DOI 10.1002/sce.20338

18. U.S. Census Bureau (2012). U.S. census bureau projections show a slower growing, older, more diverse nation a half century from now [Press release]. Retrieved from http://www.census.gov/newsroom/releases/archives/population/cb12-243.html

19. Lichter, D.T. (2013). Integration or fragmentation? Racial diversity and the American future. Demography, 50, 359-391.

20. Humes, K.R., Jones, N.A., \& Ramirez, R.R., (2011). Overview of race and hispanic origin: 2010. United States Census Bureau C2010BR-02. Retrieved from http://www.census.gov/prod/cen2010/briefs/c2010br$\underline{\text { 02.pdf }}$

21. Frehill, L.M., (2011). African Americans in engineering. NACME Research \& Policy Brief, 1(4), 1-2.

22. Lord, S.M., Camacho, M.M., Layton, R.A., Long, R.A., Ohland, M.W, \& Wasburn, M.H. (2009). Who’s persisting in engineering? A comparative analysis of female and male Asian, black, Hispanic, native American, and white students. Journal of Women and Minorities in Science and Engineering, 15, 167-190. 
23. Sengupta, S. (2013, June 27). A bill allowing more foreign workers stirs a tech debate. New York Times. Retrieved July 23, 2013 from http://www.nytimes.com/2013/06/28/technology/a-bill-allowing-moreforeign-workers-stirs-a-tech-debate.html?pagewanted=all\&_r=0.

24. Strayhorn, T.L. (2008). Influences on labor market outcomes of African American college graduates: A national study. The Journal of Higher Education, 79(1), 28-57.

25. Xie, Y. \& Killewald, A. (2012). Is American science in decline? Cambridge, MA: Harvard University Press.

26. McDonald, S.J. (2001). How whites explain black and Hispanic inequality. Public Opinion Quarterly, 65(5), 562-573.

27. Moss, P. \& Tilly, C. (2001). Stories employers tell: Race, skill, and hiring in America. New York, NY: Russell Sage Foundation.

28. Wilson, W.J. (1997). When work disappears. New York, NY: Random House.

29. Blauner, R. (1972). Racial oppression in America. New York, NY: Harper and Row.

30. Leslie, L.L., McClure, G.T., \& Oaxaca, R.L. (1998). Women and minorities in science and engineering. The Journal of Higher Education, 69(3), 239-276.

31. Byars-Winston, A. (2010). The vocational significance of black identity: Cultural formulation approach to career assessment and career counseling. Journal of Career Development, 37(1), 441-464.

32. Perna, L., Lundy-Wagner, V., Drezner, N.D., Gasman, M., Yoon, S. Bose, E., \& Gary, S. (2007). The contribution of HBCUs to the preparation of African American women for STEM careers: A case study. Research in Higher Education Journal, 50, 1-23.

33. Gardenswartz, L. \& Rowe, A. (2010). Managing diversity: A complete desk reference \& planning guide, third edition. Alexandria, VA: Society for Human Resource Management.

34. Gibbs, T.S. (2008). From retention to detention: A phenomenological study of the African-American engineer experience (Doctoral dissertation). Available from ProQuest Dissertations and Theses database. (UMI No. 3330380).

35. Thomas, D.A. \& Gabarro, J.J. (1999). Breaking through. Boston, MA: Harvard Business School Press.

36. Shenhav, Y. (1992). Entrance of blacks and women into managerial positions in scientific and engineering occupations: A longitudinal analysis. Academy of Management Journal, 35(4), 889-901.

37. Vallas, S.P. (2003). Rediscovering the color line with work organizations: The 'knitting of racial groups' revisited. Work and Occupations, 30(4), 379-400.

38. Kanter, R.M. (1977). Men and women of the corporation. New York, NY: BasicBooks.

39. Kanter, R.M. (1993). Men and women of the corporation. New York, NY: BasicBooks.

40. Feldman, S. \& Huddy, L. (2005). Racial resentment and white opposition to race-conscious programs: Principles or prejudice? American Journal of Political Science, 49(1), 168-183.

41. McPherson, M., Smith-Lovin, L. \& Cook, J.M. (2001). Birds of a feather: Homophily in social networks. Annual Review of Sociology, 27, 415-444.

42. Taylor, S.E. (1982). The availability bias in social perception and interaction. In D. Kahneman, P. Slovic, \& A. Tversky (Eds.), Judgement under uncertainty (pp. 190-200). Cambridge, MA: Cambridge University Press.

43. Tversky, A., \& Kahneman, D. (1982). Judgment under uncertainty: Heuristics and biases. In D. Kahneman, P. Slovic, \& A. Tversky (Eds.), Judgement under uncertainty (pp. 3-22). Cambridge, MA: Cambridge University Press.

44. Thompson, M.S. \& Keith, V.M. (2001). The blacker the berry: Gender, skin tone, self-esteem and selfefficacy. Gender \& Society, 15(3), 336-357.

45. Dobbin, F., Kalev, A., \& Kelly, E. (2007). Diversity management in corporate America. American Sociological Association, 6(4), 21-27.

46. Chemers, M.M., Zurbriggen, E.L., Syed, M., Goza, B.K, \& Bearman, S. (2011). The role of efficacy and identity in science career commitment among underrepresented minority students. Journal of Social Issues, 67(3), 469-491. 
47. Kalev, A., Dobbin, F., \& Kelly, E. (2006). Best practices or best guesses? Assessing the efficacy of corporate affirmative action and diversity policies. American Sociological Review, 71, 589-617.

48. Dobbin, F. \& Kalev, A. (2007). The architecture of inclusion: Evidence from corporate diversity programs. Harvard Journal of Law \& Gender, 30, 279-301.

49. Dobbin, F., Kim, S., \& Kalev, A. (2011). You can’t always get what you need: Organizational determinates of diversity programs. American Sociological Review, 76(386), 386-411.

50. Bunton, W. (2000). Best practices in achieving workforce diversity. Benchmarking study of the U.S. Department of Commerce and Vice President Al Gore's National Partnership for Reinventing Government. Retrieved on September 13, 2013 from http://govinfo.library.unt.edu/npr/library/workforce-diversity.pdf

51. Standen, A. (July 23, 2012). Silicon valley boot camp aims to boost diversity. Retrieved from www.npr.org/2012/07/23/156555402/silicon-valley-boot-camp-aims-to-boost-diversity

52. Watson, K. \& Froyd, J. (2007). Diversifying the U.S. engineering workforce: A new model. Journal of Engineering Education, 96(1), 19-32.

53. Whitworth, T. (2012). How to manage diversity at work. Public Finance, June, 42-43.

54. Brathwaite, S.T. (2002). Denny's: A diversity success story. Franchising World, 34(5), 28-29.

55. Bandura, A. (1985). Social foundations of thought and action: A social cognitive theory. Englewood Cliffs, NJ: Prentice Hall.

56. Bandura, A. (1997a). Self-efficacy: The exercise of control. New York, NY: W.H. Freeman and Company.

57. Bandura, A. (1989). Regulation of cognitive processes through perceived self-efficacy. Developmental Psychology, 25(5), 729-735.

58. Pajares, F. (1997). Current directions in self-efficacy research. In M. Maehr \& P. R. Pintrich (Eds.). Advances in motivation and achievement. Volume 10, (pp. 1-49). Greenwich, CT: JAI Press.

59. Bandura, A. (1977). Self-efficacy: Toward a unifying theory of behavioral change. Psychological Review, 84(2), 191-215.

60. Bandura, A. (1977). Social learning theory. Upper Saddle River, NJ: Prentice Hall.

61. Bandura, A. (2012). On the functional properties of perceived self-efficacy revisited. Journal of Management, 38(1), 9-44.

62. Noble, R. (2011). Mathematics self-efficacy and African American male students: An examination of two models of success. Journal of African American Males in Education, 2(2), 188-213.

63. Bandura, A. (2001). Social cognitive theory: An agentic perspective. Annual Review of Psychology, 52, 126

64. Bandura, A. (1997b). Self-efficacy. Harvard mental Health Letter, 13(9), 4-6.

65. Betz, N. (2001). Career self-efficacy. In F.T.L. Leong \& A. Barak (Eds). Contemporary models in vocational psychology: A volume in honor of Samuel H. Osipow (pp. 55-77). Mahwah, New Jersey: Lawrence Erlbaum Associates.

66. Betz, N.E. \& Luzzo, D.A. (1996). Career assessment and the career decision-making self-efficacy scale. Journal of Career Assessment, 4(4), 413-428.

67. Beeftink, F., Van Eerde, W., Rutte, C.G., \& Bertrand, J.W.M. (2012). Being successful in a creative profession: The role of innovative cognitive style, self-regulation, and self-efficacy. Journal of Business Psychology, 27, 71-81.

68. Gecas, V. (1989). The social psychology of self-efficacy. Annual Review of Sociology, 15, 291-316.

69. Gloria, A.M. \& Hird, J.S. (1999). Influences of ethnic and nonethnic variables on the career decisionmaking self-efficacy of college students. The Career Development Quarterly, 48(2), 157-174.

70. Liff, S. (2007). Managing government employees: How to motivate your people, deal with difficult issues, and achieve tangible results. New York, NY: American Management Association.

71. Betz, N.E., Hammond, M.S., \& Multon, K.D. (2005). Reliability and validity of five-level response continua for the career decision self-efficacy scale. Journal of Career Assessment, 13(2), 131-149.

72. Liff, S. (2011). Improving the performance of government employees: A manager's guide. New York, NY: American Management Association. 
73. Hartman, R.O. \& Betz, N.E. (2007). The five-factor model and career self-efficacy: General and domainspecific relationships. Journal of Career Assessment, 15(3), 145-161.

74. Witherspoon, K.M. \& Speight, S.L. (2009). An exploration of African Americans' interests and selfefficacy beliefs in traditional and nontraditional careers. Journal of Black Studies, 29(6), 888-904.

75. Betz, N.E. \& Gwilliam, L.R. (2002). The utility of measures of self-efficacy for the Holland themes in African American and European American college students. Journal of Career Assessment, 10(3), 283-300.

76. Gwilliam, L.R., Betz, N.E. (2001). Validity of measures of math- and science-related self-efficacy for African Americans and European Americans. Journal of Career Assessment, 9(3), 261-281.

77. Schyns, B. \& Sczesny, S. (2009). Leadership attributes valence in self-concept and occupational selfefficacy. Career Development International, 15(1), 78-92.

78. Byars-Winston, A.M. \& Fouad, N.A. (2008). Math and science social cognitive variables in college students: Contributions of contextual factors in predicting goals. Journal of Career Assessment, 16, 425440.

79. Marra, R.M., Rodgers, K.A., Shen, D., \& Bogue, B. (2009). Women engineering students and self-efficacy: A multi-year, multi-institution study of women engineering student self-efficacy. Journal of Engineering Education, 98(1), 27-38.

80. Betz, N.E. \& Borgen, F.H. (2009). Comparative effectiveness of CAPA and FOCUS online: Career assessment systems with undecided college students. Journal of Career Assessment, 17(4), 351-366.

81. Kolodinsky, P., Schroder, V., Montopoli, G., McLean, S., Mangan, P. \& Person, W. (2006). The career fair as a vehicle for enhancing occupational self-efficacy. Professional School Counseling, 10(2), 161-167.

82. Gushue, G.V., Scanlan, K.R.L., Pantzer, K.M., \& Clarke, C.P. (2006). The relationship of career decisionmaking self-efficacy, vocational identity, and career exploration behavior in African American high school students. Journal of Career Development, 33(1), 19-28.

83. Carberry, A.R., Lee, H., Ohland, M.W. (2010). Measuring engineering design self-efficacy. Journal of Engineering Education, 99(1), 71-79.

84. Dunlap, J.C. (2005). Problem-based learning and self-efficacy: How a capstone course prepares students for a profession. Educational Technology Research and Development, 53(1), 65-85.

85. Betz, N.E., (2003). A proactive approach to midcareer development. The Counseling Pschologyist, 31(2), 205-211.

86. Betz, N.E. (2004). Contributions of self-efficacy theory to career counseling: A personal perspective. The Career Development Quarterly, 52(4), 340-353.

87. Taylor, K. M., \& Betz, N. E. (1983). Applications of self-efficacy theory to the understanding and treatment of career indecision. Journal of Vocational Behavior, 22, 63-81.

88. Compeau, D., Higgins, C. \& Huff, S. (1999). Social cognitive theory and individual reactions to computing technology: A longitudinal study. MIS Quarterly, 23(2), 145-158.

89. Fouad, N.A., Smith, P.L., \& Zao, K.E. (2002). Across academic domains: Extensions of the social-cognitive career model. Journal of Counseling Psychology, 49(2), 164-171.

90. Schaub, M. \& Tokar, D.M. (2005). The role of personality and learning experiences in social cognitive career theory. Journal of Vocational Behavior, 66, p. 304-325.

91. Tokar, D.M., Thompson, M.N., Plaufcan, M.R., \& Williams, C.M. (2007). Precursors of learning experiences in social cognitive career theory. Journal of Vocational Behavior, 71, 319-339.

92. Crites, J.O. \& Savickas, M.L. (1996). Revision of the career maturity inventory. Journal of Career Assessment, 4(2), 131-138.

93. Westbrook, B.W., Cutts, C.C., Madison, S.S., \& Arcia, M.A. (1980). The validity of the Crites model of career maturity. Journal of Vocational Behavior 16, 249-281.

94. Crites, J.O. (1978). Career maturity inventory. Monterey, CA: CTB/McGraw-Hill.

95. Hansen, J.C. (1974). Book review of J.O. Crites career maturity inventory. Journal of Career Counseling, 21(2), 168-172. 
96. Sherer, M., Maddux, J.E., Mercandante, B., Prentice-Dunn, S., Jacobs, B., \& Rogers, R.W. (1982). The self-efficacy scale: Construction and validation. Psychological Reports, 51(2), 663-671.

97. Bosscher, R.J. \& Smit, J.H. (1998). Confirmatory factor analysis of the general self-efficacy scale. Behaviour Research and Therapy, 36, 339-343.

98. Bandura, A. (2005). Guide for constructing self-efficacy scales (Chapter 14). Self-efficacy beliefs of adolescents, 307-337. Charlotte, NC: Information Age Publishing.

99. Betz, N.E. \& Rottinghaus, P.J. (2006). Current research on parallel measures of interests and confidence for basic dimensions of vocational activity. Journal of Career Assessment, 14(1), 56-76.

100. Paulson, A.M., \& Betz, N.E. (2004). Basic confidence predictors of career decision-making self-efficacy. The Career Development Quarterly, 54, 354-362.

101. Robinson, C.H. \& Betz, N.E. (2004). Test-restest reliability and concurrent validity of the expanded skills confidence inventory. Journal of Career Assessment, 12(4), 407-422.

102. Borgen, F.H. \& Betz, N.E. (2008). Career self-efficacy and personality linking career confidence and the healthy personality. Journal of Career Assessment, 16(1), 22-43.

103. Niles, S.G. \& Sowa, C.J. (1992). Mapping the normological network of career self-efficacy. Career Development Quarterly, 41(1), 13-22.

104. Nilsson, J.E., Schmidt, C.K., \& Meek, W.D. (2002). Reliability generalization: an examination of the career decision-making self-efficacy scale. Educational and Psychological Measurement, 62(4), 647-658.

105. Blancero, D.M. \& DelCampo, R.G. (2005). Hispanics in the workplace: Experiences with mentoring and networking. Employment Relations Today, 31-38. Published online in Wiley InterScience (www.interscience.wiley.com). DOI 10.1002/ert.20061

106. Dempsey, J.K. \& Shapiro, R.Y. (2009). The army's Hispanic future. Armed Forces \& Society, 35, 526-555.

107. Anderson, S.L. \& Betz, N.E. (2001). Sources of social self-efficacy expectations: Their measurement and relation to career development. Journal of Vocational Behavior, 58, 98-117.

108. Moynihan, L.M., Roehling, M.V., LePine, M.A., \& Boswell, W.R. (2003). A longitudinal study of the relationship among job search self-efficacy, job interviews, and employment outcomes. Journal of Business and Psychology, 18(2), 207-233.

109. Santiago, A.M., \& Einarson, M.K., (1998). Background characteristics as predictors of academic selfconfidence and academic self-efficacy among graduate students. Research in Higher Education, 39(2), 163-198.

110. Zajacova, A., Lynch, S.M., \& Espenshade, T.J. (2005). Self-efficacy, stress, and academic success in college. Research in Higher Education, 46(6), 677-706.

111. Lent, R.W. \& Hackett, G. (1987). Career self-efficacy: Empirical status and future directions. Journal of Vocational Behavior, 30, 347-382.

112. Betz, N.E. \& Hackett, G. (2006). Career self-efficacy theory: Back to the future. Journal of Career Assessment, 14(1), 3-11.

113. Lindley, L.D. (2006). The paradox of self-efficacy: Research with diverse populations. Journal of Career Assessment, 14(1), 143-160.

114. Chaney, D., Hammond, M.S., Betz, N.E., \& Multon, K.D. (2007). The reliability and factor structure of the career decision self-efficacy scale-SF with African americans. Journal of Career Assessment, 15(2), 194205.

115. Pajares, F. (1996). Self-efficacy beliefs in academic settings. Review of Educational Research, 66(4), 543578.

116. Fraenkel, J.R. \& Wallen, N.E. (2009). How to design and evaluate research in education, seventh edition. New York, NY: McGraw-Hill.

117. Leedy, P.D. \& Ormrod, J.E. (2010). Practical research, ninth edition. Upper Saddle River, NJ: Merrill.

118. Owens, L.K. (2002). Introduction to survey research design. Retrieved from http://srl/uic.edu

119. Parker, L. (2004). Engineers in the United States: An overview of the profession. Engineering Workforce Project Report \#2, Cambridge, MA: Abt Associates Inc. 
120. Cook, T.D. \& Campbell, D.T. (1979). Quasi-experimentation: Design and analysis issues for field settings. Chicago, IL: Rand McNally.

121. Adams, J.A. (2008, March). Statistical validity pitfalls. Paper presented at the Metrics for HRI, Nashville, TN. Retrieved from http://www.hri-metrics.org/metrics08/Adams_HRIMetrics08.pdf

122. Hammond, M.S., Betz, N.E., Multon, K.D., \& Irvin, T. (2010). Super’s work values inventory-revised scale validation for African Americans. Journal of Career Assessment, 18(3), 266-275.

123. Luzzo, D. A. (1993). Reliability and validity testing of the career decision-making self-efficacy scale. Measurement and Evaluation in Counseling and Development, 26, 137-142.

124. Betz, N.E., \& Klein, K.L. (1996). Relationships among measures of career self-efficacy, generalized selfefficacy, and global self-esteem. Journal of Career Assessment, 4(3), 285-298.

125. Vacha-Haase, T. (1998). Reliability generalization: Exploring variance in measurement effort affecting some reliability across studies. Educational and Psychological Measurement, 58(1), 6-20.

126. Hamilton, M.B. (2009). Online survey response rates and times: Background and guidance for industry [White Paper]. Ipathia. Retrieved from http://www.supersurvey.com/papers/supersurvey_white_paper_response_rates.htm

127. Arleck, P.L. \& Settle, R.B. (1995). The survey research handbook, second edition. New York, NY: McGraw-Hill.

128. Hoerger, M. (2010). Participant dropout as a function of survey length in internet-mediated university studies: Implications for study design and voluntary participation in psychological research. Cyberpsychology, Behavior, and Social Networking, 13(6), 697-700.

129. Peterson, S.L. (1993). Career decision-making self-efficacy and institutional integration of underprepared college students. Research in Higher Education, 34(6), 659-685.

130. Rollins, V. \& Valdez, J.N. (2006). Perceived racism and career self-efficacy in African American adolescents. The Journal of Black Psychology, 32(2), 176-198.

131. Lent, R.W. \& Fouad, N.A. (2011). The self as agent in social cognitive career theory. In P.J. Hartung \& L.M. Subich (Eds.), Developing self in work and career: Concepts, cases, and contexts (pp. 71-87). Washington, DC: American Psychological Association.

132. Martin-Vega, L.A. (2006). Hispanics in engineering. ASEE Prism, 15(6), 46.

"Approved for public release; distribution is unlimited. The views and opinions expressed herein are strictly those of the author and do not represent or reflect those of the United States Government." 